\title{
Pemodelan dan Simulasi Produksi Biogas dari Substrat Glukosa Menggunakan Anaerobic Digestion Model No. 1 (ADM1)
}

\author{
Isman Kurniawan ${ }^{\# 1}$, Annisa Aditsania ${ }^{* 2}$ \\ \#1 Computational Science Department, Telkom University \\ Jl. Telekomunikasi, Terusan Buah Batu, Bandung, 40257, Indonesia \\ *2 Computational Science Department, Telkom University \\ Jl. Telekomunikasi, Terusan Buah Batu, Bandung, 40257, Indonesia \\ ${ }^{1}$ ismankrn@telkomuniversity.ac.id \\ 2 aaditsania@telkomuniversity.ac.id
}

\begin{abstract}
This aim of this research is conducting biogas production modeling using Anaerobic Digestion Model No. 1 (ADM1). This modeling is required to increase effectiveness and efficiency in biogas production as the solution of trial and error method implementation in determining production parameter. Initial simulation was performed using recommended parameter and its result will be used to determine the accuracy. Simulation result shows similar trend compare to experimental data. The accuracy of calculation is improved by optimize the simulation parameter. The number of parameter was reduced by calculate the sensivity indices of each parameter. Optimization process using genetic algorithm produce new optimized parameter value. The value of mean average percentage error (MAPE) of simulation using standard parameter and optimized parameter are $22,54 \%$ and $0,08 \%$, respectively. It shows that simulation using optimized parameter give better accuracy. Simulation results shows the glucose concentration decrease significantly in the beginning of process and methane concentration increase simultaneously. The final concentration of methane after $500 \mathrm{mgCOD} / \mathrm{L}$ of glucose decomposed is $354,79 \mathrm{mgCOD} / \mathrm{L}$.
\end{abstract}

Keywords: ADM1, biogas, genetic algorithm, methane.

\begin{abstract}
Abstrak
Penelitian ini bertujuan untuk memodelkan produksi biogas dengan menggunakan Anaerobic Digestion Model No. 1 (ADM1). Pemodelan ini diperlukan untuk meningkatkan efektivitas dan efisiensi dalam produksi biogas sebagai solusi dari metode trial and error dalam penentuan parameter produksi. Simulasi awal dilakukan dengan menggunakan parameter yang direkomendasikan dan hasilnya digunakan untuk menentukan akurasi perhitungan. Hasil simulasi menunjukkan kecenderungan yang sama dengan data eksperimen. Akurasi perhitungan diperbaiki dengan mengoptimasi parameter simulasi. Jumlah parameter yang dioptimasi direduksi dengan menghitung indeks sensitivitas dari masing-masing parameter. Proses optimasi parameter menggunakan algoritma genetika menghasilkan nilai parameter baru yang teroptimasi. Nilai mean average percentage error (MAPE) untuk simulasi dengan parameter standar dan teroptimasi berturut-turut $22,54 \%$ dan $0,08 \%$. Hal ini menunjukkan bahwa simulasi dengan parameter teroptimasi menghasilkan perhitungan yang lebih akurat. Hasil simulasi menunjukkan bahwa konsentrasi glukosa mengalami penurunan yang signifikan di awal proses bersamaan dengan kenaikan konsentrasi metana. Konsentrasi akhir metana yang didapat setelah $500 \mathrm{mgCOD} / \mathrm{L}$ glukosa terurai adalah $354,79 \mathrm{mgCOD} / \mathrm{L}$.
\end{abstract}

Kata Kunci: ADM1, algoritma genetika, biogas, metana. 


\section{Pendahuluan}

$\mathbf{P}$ ENGEMBANGAN sumber energi terbarukan merupakan salah satu topik yang menarik untuk diteliti. Hal ini sangat berkaitan dengan kondisi saat ini yang sangat bergantung pada penggunaan sumber energi yang tidak terbarukan, yaitu minyak bumi dan gas alam. Ketersediaan sumber energi tersebut sulit diprediksi dengan akurat, tetapi habisnya sumber energi tersebut adalah suatu kepastian. Oleh karena itu proses pengembangan sumber energi alternatif terbarukan perlu dilakukan untuk mengantisipasi kondisi tersebut. Pada proses pengembangannya, dampak penggunaan sumber energi terhadap lingkungan harus menjadi perhatian. Hal ini perlu dilakukan untuk menciptakan sinergi antara eksploitasi energi dan konservasi lingkungan. [1]

Salah satu alternatif sumber energi yang ramah lingkungan adalah biogas. Biogas merupakan sumber energi yang dihasilkan melalui proses pencernaan anaerobik dari sisa kotoran hewan ternak, sisa makanan, lumpur sisa pengolahan air dan limbah organik lainnya. [2] Pemanfaatan limbah dalam produksi biogas menjadi keunggulan tersendiri dari sumber energi ini. Oleh karena itu, pengembangan produksi biogas akan sangat menguntungkan baik dari aspek energi maupun aspek lingkungan. Pada kasus industri yang menghasilkan limbah organik, integrasi proses produksi dengan instalasi produksi biogas di akhir produksi dapat menurunkan biaya produksi secara keseluruhan. Hal ini dikarenakan pemanfaatan energi biogas dapat mensubstitusi sebagian kebutuhan energi di industri.

Proses produksi biogas melibatkan beberapa parameter yang cukup kompleks. Beberapa parameter tersebut di antaranya $\mathrm{pH}$, temperatur, jenis reaktor, jenis mikroba. Keterlibatan parameter-parameter tersebut mengakibatkan proses optimasi produksi menjadi sulit untuk dilakukan. Proses optimasi diperlukan untuk menghasilkan kinerja produksi dengan jumlah biogas yang dihasilkan seoptimal mungkin. Proses optimasi secara trial and error dengan eksperimen akan membutuhkan waktu dan biaya yang besar. Untuk mengatasi masalah ini, maka pemodelan dan simulasi dari produksi biogas dapat dilakukan untuk mendapatkan kombinasi parameter yang tepat. Pada dasarnya pemodelan dilakukan berdasarkan proses kimiawi dan fisis yang terjadi pada saat biogas diproduksi. Oleh karena itu, pemahaman mengenai mekanisme proses dan kinetika dibutuhkan untuk implementasi model tersebut. Selain itu, pemahaman tersebut juga diperlukan untuk dapat mendesain reaktor yang tepat sehingga produksi gas metana dapat diprediksi berdasarkan kondisi operasi yang digunakan. [3]

Salah satu model yang telah banyak digunakan untuk memodelkan suatu proses anaerobik adalah Anaerobic Digestion Model No. 1 (ADM1). [8] [9] [10] [11] Model ini dikembangkan pertama kali oleh International Water Association (IWA) pada tahun 2002. Model ini mempertimbangkan kinetika dari proses biokimia dan fisiko-kimia yang terjadi selama proses produksi biogas. Model ADM1 sangat tepat digunakan untuk melihat efek dari perubahan parameter-parameter seperti konsentrasi substrat, temperatur, $\mathrm{pH}$, terhadap jumlah biogas yang dihasilkan. [1] Penelitian sebelumnya telah dilakukan untuk memodelkan produksi biogas dari substrat glukosa dengan menggunakan ADM1. [4] Penelitian tersebut menyederhanakan model ADM1 dengan mengabaikan proses inhibisi $\mathrm{pH}$ terhadap aktivitas mikroba sehingga kurang merepresentasikan proses yang sebenarnya. Penelitian ini melengkapi penelitian sebelumnya dengan mempertimbangkan proses inhibisi di dalam model. Akurasi model perhitungan dilakukan dengan membandingkan hasil simulasi dengan data eksperimen yang digunakan pada penelitian sebelumnya. [4] Akurasi perhitungan diperbaiki dengan mengoptimasi parameter simulasi dengan menggunakan algoritma genetika sebagaimana yang dilakukan pada penelitian sebelumnya.

\section{Metode Penelitian}

Pada penelitian ini, model ADM1 digunakan memodelkan profil kinetika dari masing-masing spesi yang terlibat dalam proses. Kondisi yang digunakan pada pemodelan dan simulasi disesuaikan dengan kondisi eksperimen rujukan sehingga hasil simulasi layak untuk dibandingkan dengan data eksperimen. [4] Substrat awal yang digunakan adalah glukosa dengan konsentrasi $500 \mathrm{mgCOD} / \mathrm{L}$ dan jenis reaktor yang dipertimbangkan pada pemodelan adalah reaktor tipe batch. [4] Komponen biogas yang dipertimbangkan pada penelitian ini adalah gas metana yang merupakan komponen utama dari biogas. Spesi metana yang terbentuk diasumsikan mengalami perubahan fasa menjadi gas secara spontan sehingga proses 


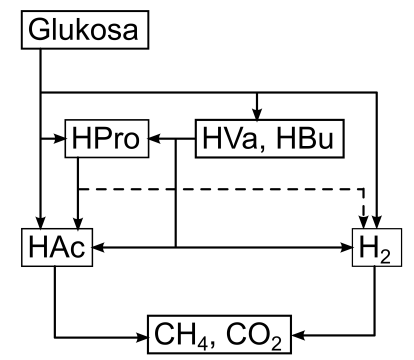

Gambar 1. Skema proses biokimia yang dipertimbangkan.

transfer gas diabaikan. Selain itu konsentrasi spesi karbondioksida diabaikan karena konsentasi sangat kecil dibandingkan konsentrasi spesi lain. Pengkodean untuk simulasi dan optimasi parameter algoritma genetika diselesaikan menggunakan perangkat lunak GNU Octave. [5]

\section{A. Model Kinetika Reaksi}

Model kinetika reaksi digunakan untuk memprediksi profil kinetika dari masing-masing spesi yang terlibat dalam reaksi. Substrat awal yang digunakan, yaitu glukosa, menentukan jumlah proses yang digunakan dari keseluruhan proses yang terdapat di ADM1. Pada dasarnya terdapat 2 jenis proses yang dipertimbangkan pada ADM1, yaitu proses biokimia dan proses fisiko-kimia. Proses biokimia yang terjadi pada substrat ditunjukkan pada Gambar 1 dan selanjutnya diturunkan menjadi 10 reaksi pertama pada Tabel I dan II. Secara umum reaksi-reaksi tersebut adalah penguraian glukosa, asam butirat, asam asetat dan hidrogen membentuk metana. Masing-masing reaksi penguraian tersebut diimbangi dengan pertumbuhan dan pembusukan mikroba. Proses 11-14 pada Tabel II merupakan proses cair-cair yang dipertimbangkan sebagai asosiasi-disosiasi ion.

TABEL I

MATRIKS STOIKIOMETRI UNTUK SPESI TERLARUT

\begin{tabular}{|c|c|c|c|c|c|c|c|c|c|}
\hline Komponen & nponen & 1 & 2 & 3 & 4 & 5 & 6 & 7 & Pers. \\
\hline $\mathbf{j}$ & Proses & $\mathbf{S}_{\mathrm{su}}$ & $\mathbf{S}_{\mathrm{bu}}$ & $\mathrm{S}_{\text {pro }}$ & $\mathbf{S}_{\mathrm{ac}}$ & $\mathrm{S}_{\mathrm{h} 2}$ & $\mathrm{~S}_{\mathrm{ch} 4}$ & $\mathrm{~S}_{\text {IC }}$ & Laju \\
\hline 1 & Penguraian glukosa & -1 & $\left(1-Y_{s u}\right) f_{b u, s u}$ & $\left(1-Y_{s u}\right) f_{p r o, s u}$ & $\left(1-Y_{s u}\right) f_{a c, s u}$ & $\left(1-Y_{s u}\right) f_{h 2, s u}$ & & $-\Sigma_{i} C_{i} v_{i, 5}$ & $\rho 5$ \\
\hline 2 & Penguraian butirat & & -1 & & $\left(1-Y_{c 4}\right) 0.8$ & $\left(1-Y_{c 4}\right) 0.2$ & & & $\rho 99$ \\
\hline 3 & Penguraian propionat & & & -1 & $\left(1-Y_{\text {pro }}\right) 0.57$ & $\left(1-Y_{\text {pro }}\right) 0.43$ & & $-\Sigma_{i} C_{i} v_{i, 10}$ & $\rho 10$ \\
\hline 4 & Penguraian asetat & & & & -1 & & $\left(1-Y_{a c}\right)$ & $-\Sigma_{i} C_{i} v_{i, 11}$ & $\rho 11$ \\
\hline 5 & Penguraian hidrogen & & & & & -1 & $\left(1-Y_{h 2}\right)$ & $-\Sigma_{i} C_{i} v_{i, 12}$ & $\rho 12$ \\
\hline
\end{tabular}

TABEL II

MATRIKS STOIKIOMETRI UNTUK SPESI MIKROBA DAN IONIK

\begin{tabular}{|c|c|c|c|c|c|c|c|c|c|c|c|}
\hline Komponen & ponen & 8 & 9 & 10 & 11 & 12 & 13 & 14 & 15 & 16 & \multirow{2}{*}{$\begin{array}{l}\text { Pers. } \\
\text { Laju }\end{array}$} \\
\hline $\mathbf{j}$ & Proses & $\mathrm{X}_{\mathrm{su}}$ & $\mathrm{X}_{\mathrm{c4}}$ & $\mathrm{X}_{\text {pro }}$ & $\mathrm{X}_{\mathrm{ac}}$ & $\mathrm{X}_{\mathrm{h} 2}$ & $\mathbf{S}_{\text {bu- }}$ & $\mathbf{S}_{\text {pro- }}$ & $\mathrm{S}_{\mathrm{ac}-}$ & $\mathrm{S}_{\text {hco3- }}$ & \\
\hline 1 & Penguraian glukosa & $Y_{s u}$ & & & & & & & & & $\rho 5$ \\
\hline 2 & Penguraian butirat & & $Y_{c 4}$ & & & & & & & & $\rho 9$ \\
\hline 3 & Penguraian propionat & & & $Y_{\text {pro }}$ & & & & & & & $\rho 10$ \\
\hline 4 & Penguraian asetat & & & & $Y_{a c}$ & & & & & & $\rho 11$ \\
\hline 5 & Penguraian hidrogen & & & & & $Y_{h 2}$ & & & & & $\rho 12$ \\
\hline 6 & Pembusukan mikroba $X_{s u}$ & -1 & & & & & & & & & $\rho 13$ \\
\hline 7 & Pembusukan mikroba $X_{c 4}$ & & -1 & & & & & & & & $\rho 16$ \\
\hline 8 & Pembusukan mikroba $X_{\text {pro }}$ & & & -1 & & & & & & & $\rho 17$ \\
\hline 9 & Pembusukan mikroba $X_{a c}$ & & & & -1 & & & & & & $\rho 18$ \\
\hline 10 & Pembusukan mikroba $X_{h 2}$ & & & & & -1 & & & & & $\rho 19$ \\
\hline 11 & Kesetimbangan asam butirat & & & & & & -1 & & & & $\rho A 5$ \\
\hline 12 & Kesetimbangan asam propionat & & & & & & & -1 & & & $\rho A 6$ \\
\hline 13 & Kesetimbangan asam asetat & & & & & & & & -1 & & $\rho A 7$ \\
\hline 14 & Kesetimbangan asam anorganik & & & & & & & & & -1 & $\rho A 10$ \\
\hline
\end{tabular}

Jenis proses dan komponen yang digunakan pada penelitian ini ditunjukkan oleh matriks stoikiometri 
pada Tabel I dan Tabel II. Berdasarkan tabel tersebut diketahui bahwa terdapat 14 proses, yang terdiri dari 10 proses biokimia dan 4 proses fisiko-kimia. Proses fisiko-kimia yang dipertimbangkan hanya proses cair-cair berupa disosiasi dan asosiasi ion-ion. Selain itu, 16 spesi yang terlibat pada proses yang digunakan terdiri dari 7 spesi terlarut, 5 spesi partikulat mikroba, dan 4 spesi ionik. Penomoran laju pada Tabel I dan II disesuaikan dengan nomor proses yang terdapat pada ADM1. Persamaan laju reaksi untuk masing-masing proses ditunjukkan oleh persamaan 1 - 14. Terdapat 19 parameter yang terlibat di dalam perhitungan. Parameter tersebut dapat diklasifikasikan menjadi 3 jenis, yaitu parameter stoikiometri, parameter biokimia dan parameter fisiko-kimia. Nilai parameter yang digunakan pada simulasi awal mengacu pada nilai yang direkomendasikan oleh ADM1 yang didapat berdasarkan hasil optimasi untuk kondisi standar pembentukan biogas dari substrat kompleks.

$$
\begin{aligned}
& \rho 5=k_{m, s u} \frac{S_{s u}}{K_{S, s u}+S_{s u}} X_{s u} I_{5} \\
& \rho 9=k_{m, c 4} \frac{S_{b u}}{K_{S, b u}+S_{b u}} X_{c 4} I_{9} \\
& \rho 10=k_{m, p r o} \frac{S_{p r o}}{K_{S, p r o}+S_{p r o}} X_{p r o} I_{1} 0 \\
& \rho 11=k_{m, a c} \frac{S_{a c}}{K_{S, a c}+S_{a c}} X_{a c} I_{1} 1 \\
& \rho 12=k_{m, h 2} \frac{S_{h 2}}{K_{S, h 2}+S_{h 2}} X_{h 2} I_{1} 2 \\
& \rho 13=k_{d e c, X_{s u}} X_{s u} \\
& \rho 16=k_{d e c, X_{c 4}} X_{c 4} \\
& \rho 17=k_{d e c, X_{p r o}} X_{p r o} \\
& \rho 18=k_{d e c, X_{a c}} X_{a c} \\
& \rho 19=k_{d e c, X_{h 2}} X_{h 2} \\
& \rho A 5=K_{A, B_{b u}}\left(S_{b u}-\left(K_{a, b u}+S_{H^{+}}\right)-K_{a, b u} S_{b u}\right) \\
& \rho A 6=K_{A, B_{p r o}}\left(S_{p r o}-\left(K_{a, p r o}+S_{H^{+}}\right)-K_{a, p r o} S_{p r o}\right) \\
& \rho A 7=K_{A, B_{a c}}\left(S_{a c}-\left(K_{a, a c}+S_{H^{+}}\right)-K_{a, a c} S_{a c}\right) \\
& \rho A 10=K_{A, B_{c o 2}}\left(S_{c o 2}-\left(K_{a, c o 2}+S_{H^{+}}\right)-K_{a, c o 2} S_{c o 2}\right)
\end{aligned}
$$

\section{B. Model Matematika}

Model matematika yang digunakan pada penelitian ini berupa sistem persamaan diferensial yang terdiri dari 16 persamaan. Persamaan tersebut menunjukkan laju perubahan konsentrasi masing-masing spesi terhadap waktu. Kompleksitas persamaan diferensial yang digunakan sangat bergantung pada substrat awal yang digunakan. Bentuk umum dari persamaan diferensial yang digunakan ditunjukkan oleh persamaan 15. Ekspresi pada sisi kanan persamaan 15 merupakan penjumlahan laju kinetika untuk proses j $\left(\rho_{j}\right)$ dikalikan dengan nilai konstanta stoikiometrik $\left(v_{i, j}\right)$ pada Tabel I dan II. [6] Seluruh persamaan diferensial harus diselesaikan secara simultan dengan suatu metode numerik untuk mendapatkan nilai konsentrasi masing-masing spesi pada tiap waktu. Pada penelitian ini, simulasi dilakukan selama 106 jam disesuaikan dengan data eksperimen.

$$
\frac{d S}{d t}=\sum_{j=1-14} \rho_{j} v_{i, j}
$$

Proses inhibisi oleh pH dipertimbangkan untuk merepresentasikan sensitivitas aktivitas mikroba terhadap $\mathrm{pH}$ lingkungannya. Konsentrasi ion $\mathrm{H}^{+}$untuk menghitung nilai $\mathrm{pH}$ dihitung dengan menggunakan persamaan 16 dimana $\theta$ dihitung dengan persamaan 17. [7] Seluruh persamaan diferensial diselesaikan dengan menggunakan Livermore Solver for Ordinary Differential Equation (LSODE) pada GNU Octave dimana hanya diperlukan satu nilai awal untuk memprediksi nilai pada waktu selanjutnya. 


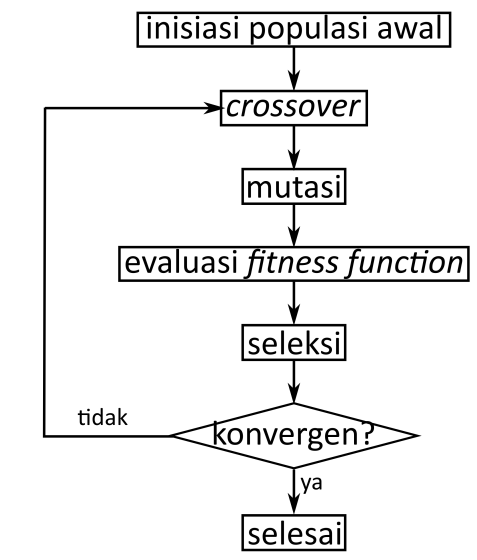

Gambar 2. Diagram alir algoritma genetika.

$$
\begin{aligned}
& S_{H^{+}}=-\frac{\theta}{2}+\frac{1}{2} \sqrt{\theta^{2}+4 K_{w}} \\
& \theta=S_{c a t+}+S_{n h 4+}-S_{h c o 3-}-\frac{S_{a c-}}{64}-\frac{S_{p r o-}}{112}-\frac{S_{b u-}}{160}-\frac{S_{v a-}}{208}-S_{a n-}
\end{aligned}
$$

\section{Optimasi Parameter}

Optimasi parameter, dengan algoritma genetika, dilakukan untuk memperbaiki akurasi perhitungan dari model yang digunakan. Jumlah parameter yang dioptimasi direduksi dengan menghitung indeks sensitivitas dari masing-masing parameter. Indeks sensitivitas merupakan nilai yang merepresentasikan tingkat kontribusi suatu parameter terhadap konsentrasi spesi metana. Indeks sensitivitas dihitung dengan menggunakan persamaan 18 dimana $C_{\mathrm{STD}}, C_{\mathrm{SENS}}$ dan $N$ berturut-turut adalah hasil perhitungan dengan parameter yang disarankan, hasil perhitungan dengan parameter yang telah diubah, dan jumlah data perhitungan. [4] Perubahan nilai parameter dilakukan mulai dari $10 \%$ hingga $200 \%$ dari nilai parameter standar. Selanjutnya parameter yang akan dioptimasi ditentukan berdasarkan nilai indeks sensitivitasnya. Parameter yang memiliki nilai indeks sensitivitas yang signifikan dioptimasi dengan algoritma genetika. Fungsi kecocokan yang menjadi acuan pada proses optimasi ditunjukkan oleh persamaan 19 dimana $C_{\text {EXP }}$ dan $C_{\text {SIM }}$ berturut-turut adalah data eksperimen dan hasil simulasi. [4] Proses optimasi dengan algoritma genetika ditunjukkan oleh Gambar 2 dengan menggunakan parameter pada Tabel 2.

$$
\begin{array}{r}
\text { Indeks sensitivitas }=\frac{\sum\left|C_{\mathrm{STD}}(t)-C_{\mathrm{SENS}}(t)\right|}{N} \\
\text { Fungsi kecocokan }=\min \left(\frac{\sum\left|C_{\mathrm{EXP}}(t)-C_{\mathrm{SIM}}(t)\right|}{N}\right)
\end{array}
$$

TABEL III

Parameter Algoritma GenetiKa

\begin{tabular}{|c|c|}
\hline Parameter & Nilai \\
\hline Jumlah generasi & 10 \\
\hline Ukuran populasi & 10 \\
\hline Peluang crossover & 1 \\
\hline Jumlah titik crossover & 1 \\
\hline Peluang mutasi & $10 \%$ \\
\hline Strategi pemilihan & Russian Roulette \\
\hline
\end{tabular}




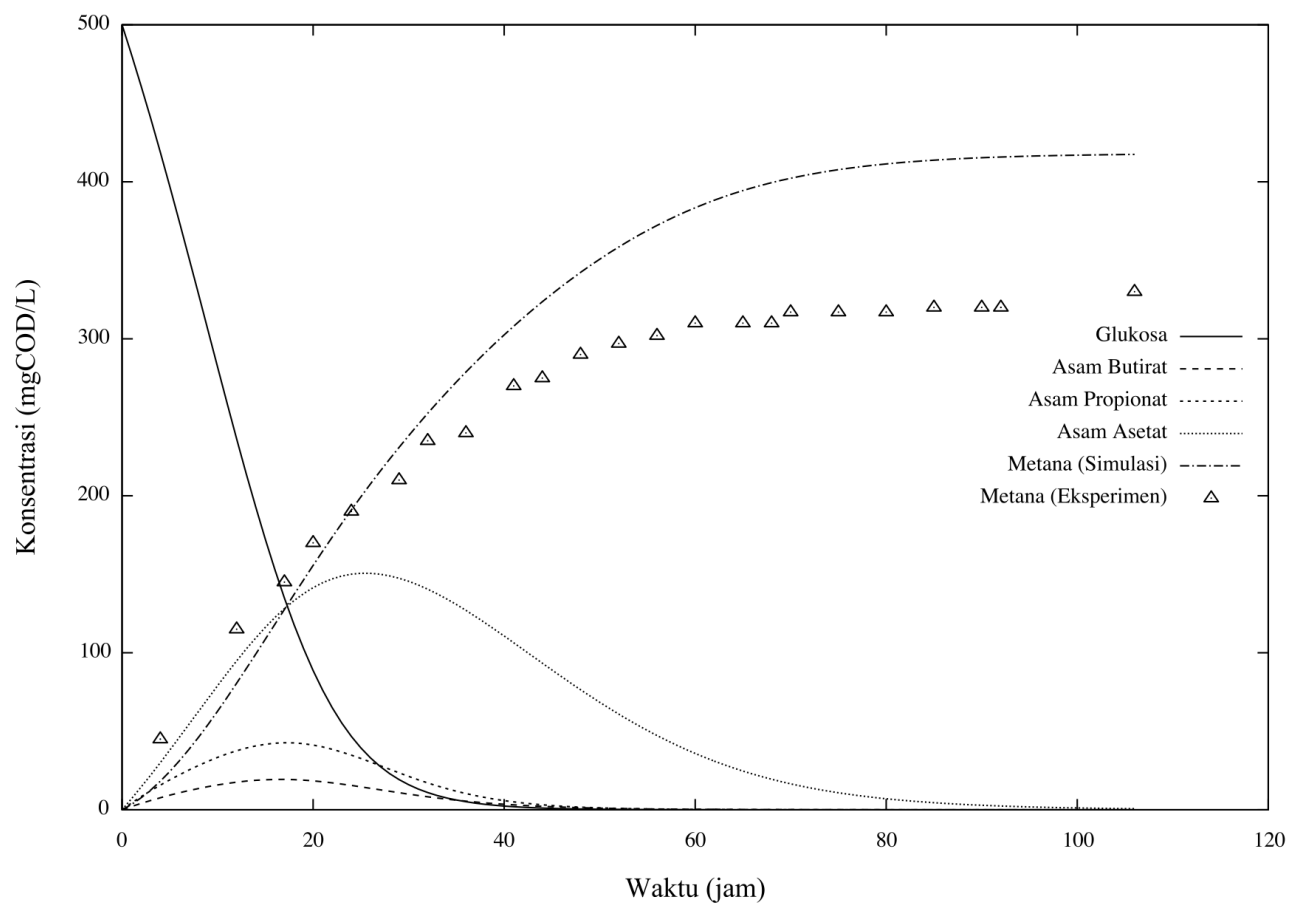

Gambar 3. Perbandingan hasil simulasi menggunakan parameter standar dan data eksperimen.

\section{HASIL DAN PEMBAHASAN}

Hasil simulasi pada Gambar 3 menunjukkan perbandingan hasil simulasi dengan data eksperimen. Berdasarkan perbandingan diketahui bahwa terdapat kesamaan pada pola kenaikan konsentrasi metana pada hasil simulasi dan eksperimen. Hal ini mengindikasikan bahwa model yang digunakan cukup valid dari aspek periodik tetapi masih bermasalah dari aspek akurasi. Selisih nilai konsentrasi metana hasil simulasi dan data eksperimen kecil di awal dan semakin membesar di setengah periode akhir. Hal ini menunjukkan bahwa hasil perhitungan kurang akurat untuk seluruh periode waktu simulasi. Oleh karena itu hasil simulasi belum dapat merepresentasikan dinamika konsentrasi masing-masing spesi. Akurasi perhitungan di awal simulasi dapat dikarenakan kondisi awal reaksi yang hanya melibatkan glukosa dan mikroba. Kompleksitas perhitungan yang disebabkan oleh dinamika konsentrasi spesi mengakibatkan akurasi perhitungan berkurang di akhir simulasi. Selain itu akumulasi kesalahan perhitungan numerik juga dapat menyebabkan hal ini terjadi.

Akurasi perhitungan ditingkatkan dengan melakukan optimasi parameter menggunakan algoritma genetika. Parameter yang dioptimasi ditentukan dengan menentukan indeks sensitivitas dari masing-masing parameter simulasi. Hal ini dilakukan untuk mengefektifkan waktu dan sumber daya komputer yang dibutuhkan untuk proses optimasi. Gambar 4 menunjukkan indeks sensitivitas untuk seluruh parameter simulasi. Parameter yang memiliki kontribusi signifikan ditunjukkan oleh nilai indeks sensitivitas yang besar. Pada dasarnya parameter yang diuji dikelompokkan menjadi 4 kelompok, yaitu nilai $(f)$, $\left(k_{m}\right),\left(K_{S}\right)$, dan $(Y)$ dimana arti fisis dari masing-masing parameter dijelaskan pada daftar notasi. Dua parameter dari masing-masing kelompok dipilih sehingga optimasi dilakukan terhadap 8 parameter. Indeks sensitivitas menunjukkan bahwa parameter yang memberikan kontribusi signifikan adalah $f_{a c, s u}, f_{h 2, s u}, k_{m, s u}, k_{m, a c}, K_{S, s u}, K_{S, a c}, Y_{s u}$ dan $Y_{h 2}$.

Perbandingan nilai parameter standar dan parameter teroptimasi pada Tabel IV menunjukkan bahwa proses optimasi menghasilkan nilai parameter yang baru. Penggunaan nilai parameter teroptimasi akan efektif bila seluruh nilai parameter digunakan. Oleh karena itu, substitusi salah satu nilai parameter teroptimasi terhadap parameter standar tidak akan meningkatkan akurasi perhitungan. Tingkat keberhasilan optimasi parameter ditentukan oleh akurasi perhitungan simulasi menggunakan parameter teroptimasi. 
(a)

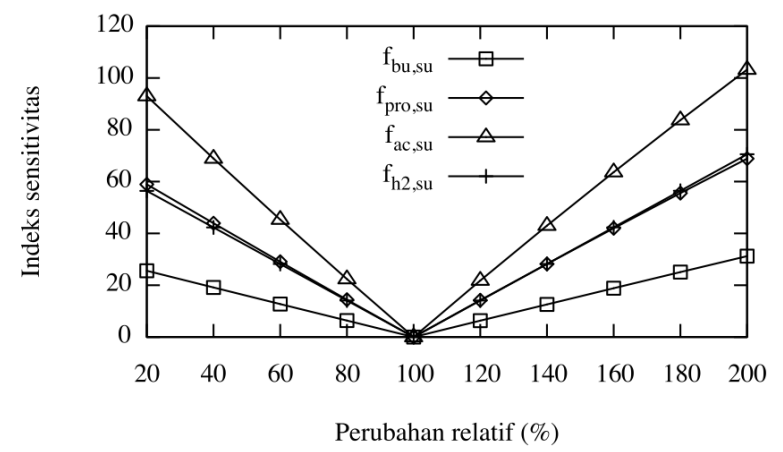

(c)

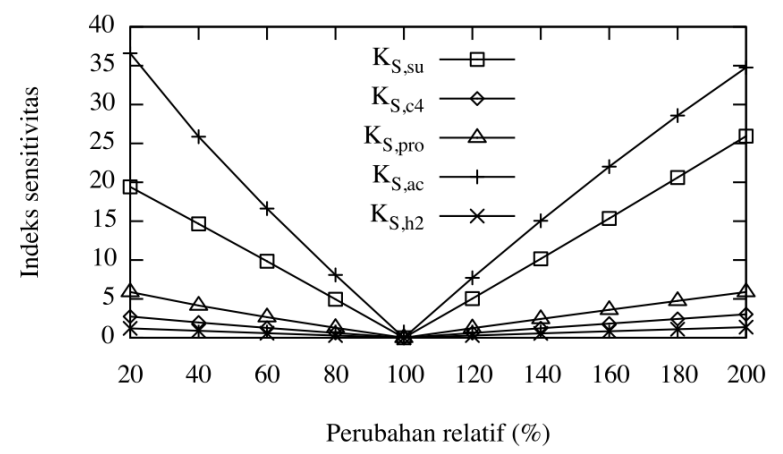

(b)

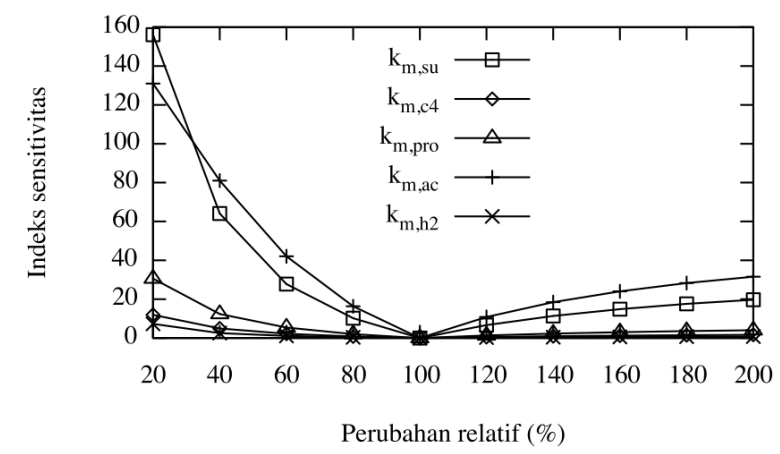

(d)

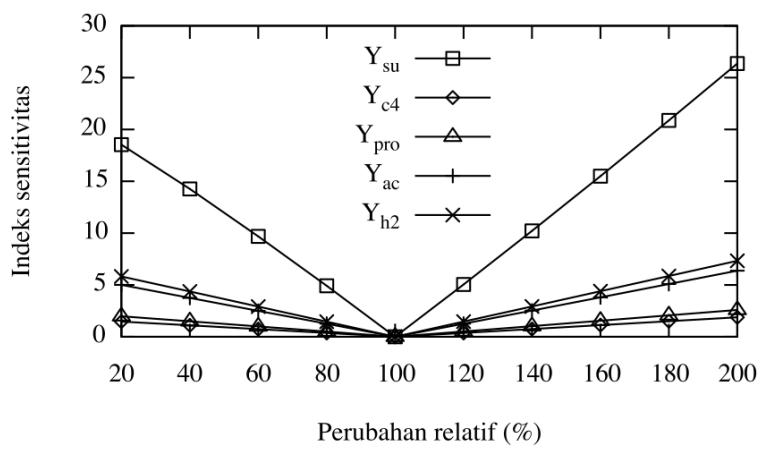

Gambar 4. Indeks sensitivitas untuk (a) hasil produk pada substrat $(f)$, (b) laju reaksi maksimum Monod spesifik $\left(k_{m}\right)$, (c) konstanta setengah jenuh Monod $\left(K_{S}\right)$, dan (d) hasil biomassa pada substrat $(Y)$.

Perbandingan antara hasil simulasi dengan parameter standar, parameter teroptimasi dan data eksperimen ditunjukkan oleh Gambar 5. Dinamika konsentrasi metana hasil simulasi menggunakan parameter teroptimasi memiliki tren yang sama dengan data eksperimen. Hal ini menunjukkan bahwa optimasi parameter tidak mengubah tren periodik dari model yang digunakan sebagaimana ditemukan di penelitian sebelumnya. [4]

TABEL IV

Perbandingan Nilai Parameter Standar dan Parameter Teroptimasi

\begin{tabular}{|c|c|c|}
\hline Parameter & Nilai Parameter Standar & Nilai Parameter Teroptimasi \\
\hline$f_{a c, s u}$ & 0,41 & 0,48 \\
\hline$f_{h 2, s u}$ & 0,19 & 0,64 \\
\hline$k_{m, s u}$ & 1,25 & 0,90 \\
\hline$k_{m, a c}$ & 0,33 & 0,77 \\
\hline$K_{S, s u}$ & 500 & 137 \\
\hline$K_{S, a c}$ & 150 & 572 \\
\hline$Y_{s u}$ & 0,10 & 0,26 \\
\hline$Y_{h 2}$ & 0,06 & 0,64 \\
\hline
\end{tabular}

Perbandingan pada Gambar 5 menunjukkan bahwa penggunaan parameter teroptimasi menghasilkan akurasi yang lebih baik di periode waktu yang lebih banyak dibandingkan penggunaan parameter standar. Tingkat akurasi perhitungan ditentukan dengan menghitung nilai Mean Average Percentage Error (MAPE) untuk masing-masing simulasi. Simulasi menggunakan parameter standar dan teroptimasi menghasilkan nilai MAPE berturut-turut $22,54 \%$ dan $0.08 \%$. Hal ini menunjukkan bahwa algoritma genetika yang 


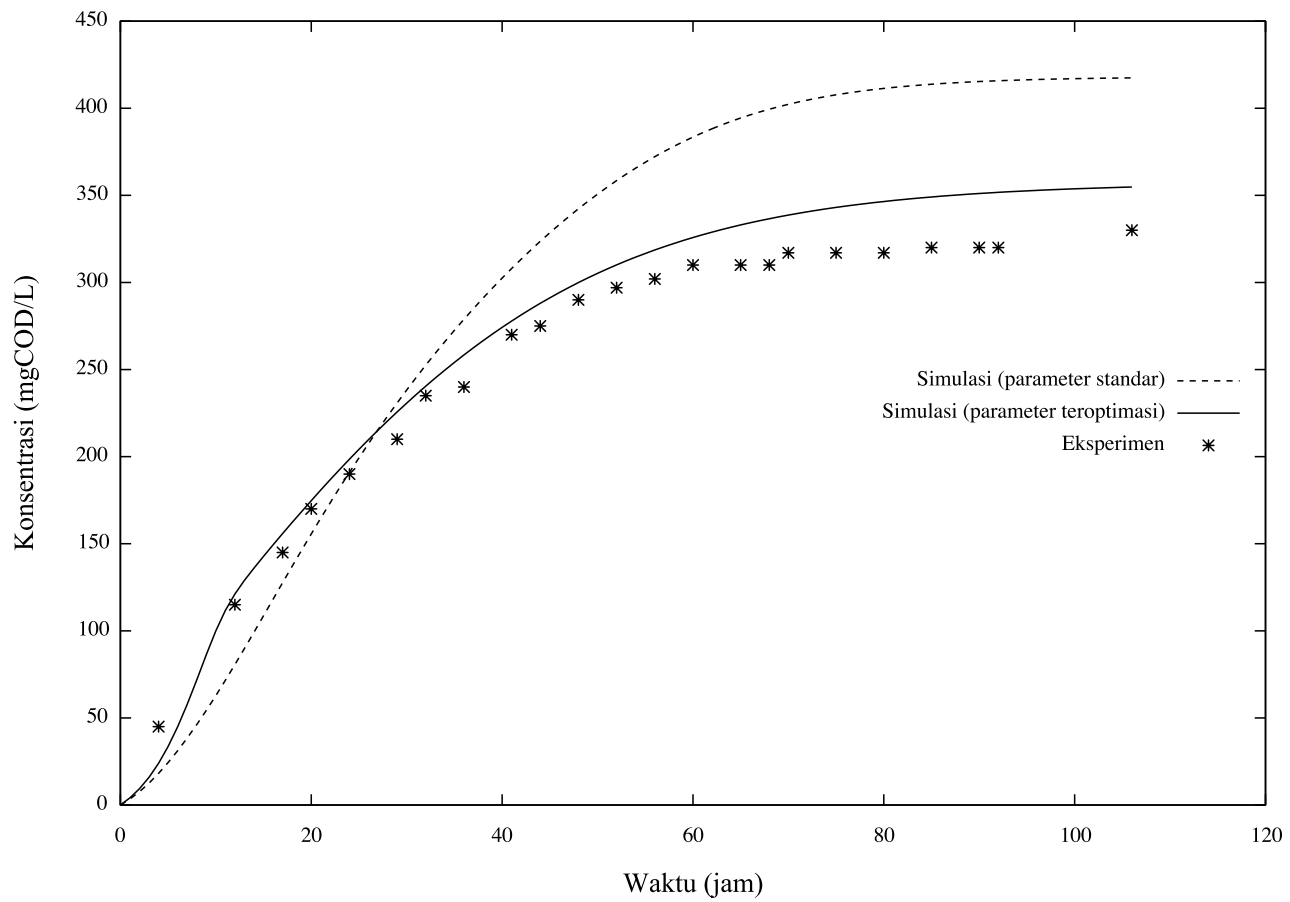

Gambar 5. Perbandingan antara hasil simulasi menggunakan parameter standar, hasil simulasi menggunakan parameter standar teroptimasi dan data eksperimen.

digunakan pada optimasi parameter cukup efektif untuk meningkatkan akurasi perhitungan. Simulasi dengan parameter teroptimasi menunjukkan akurasi yang baik pada periode awal hingga menjelang akhir simulasi dan menurun menjelang akhir simulasi. Penurunan akurasi ini dapat disebabkan oleh faktor kompleksitas perhitungan dan akumulasi kesalahan perhitungan numerik.

Peningkatan akurasi perhitungan sangat ditentukan oleh parameter pada algoritma genetika yang digunakan untuk mengoptimasi parameter. Secara umum hasil simulasi menggunakan parameter teroptimasi masih kurang akurat di periode akhir simulasi bila dibandingkan dengan penelitian sebelumnya. [4] Hal ini dikarenakan model yang digunakan pada penelitian ini lebih kompleks dibandingkan penelitian sebelumnya sehingga faktor kesalahan numerik lebih besar. Perbaikan akurasi perhitungan dengan optimasi parameter dapat dilakukan untuk mengatasi faktor ini. Salah satu parameter pada algoritma genetika yang menentukan efektivitasnya adalah jumlah generasi yang merupakan total iterasi perhitungan yang dilakukan. Oleh karena itu, peningkatan jumlah generasi akan mengakibatkan waktu perhitungan lebih lama sehingga perlu diimbangi dengan peningkatan sumber daya komputer yang digunakan.

Dinamika konsentrasi spesi yang terlibat pada simulasi dapat dijelaskan melalui hasil simulasi dengan parameter teroptimasi pada Gambar 6. Hasil simulasi menunjukkan bahwa konsentrasi glukosa mengalami penurunan yang signifikan di awal reaksi hingga habis setelah 17 jam. Hal ini menunjukkan bahwa proses konversi glukosa menjadi spesi asam cukup cepat dikarenakan tingginya aktivitas mikroba pengurai glukosa. Gas metana mengalami peningkatan yang kurang signifikan dibandingkan penurunan konsentrasi glukosa. Hal ini dikarenakan metana berada di akhir proses sehingga membutuhkan waktu hingga dapat terbentuk.

Kecenderungan peningkatan konsentrasi metana hampir berbanding lurus dengan kecenderungan penurunan konsentrasi asam asetat. Hal ini menunjukkan bahwa dinamika konsentrasi asam asetat sangat mempengaruhi dinamika konsentrasi metana. Korelasi tersebut dapat dijelaskan melalui Gambar 1 yang menunjukkan bahwa asam asetat terkonversi langsung menjadi metana sehingga konsentrasi kedua spesi sangat berkaitan. Spesi asam asetat sendiri merupakan spesi asam yang memiliki puncak konsentrasi tertinggi dibandingkan spesi asam lainnya. Hal ini menunjukkan bahwa asam asetat dihasilkan paling banyak selama simulasi dibandingkan spesi asam yang lain. Gambar 1 menunjukkan bahwa spesi asam 


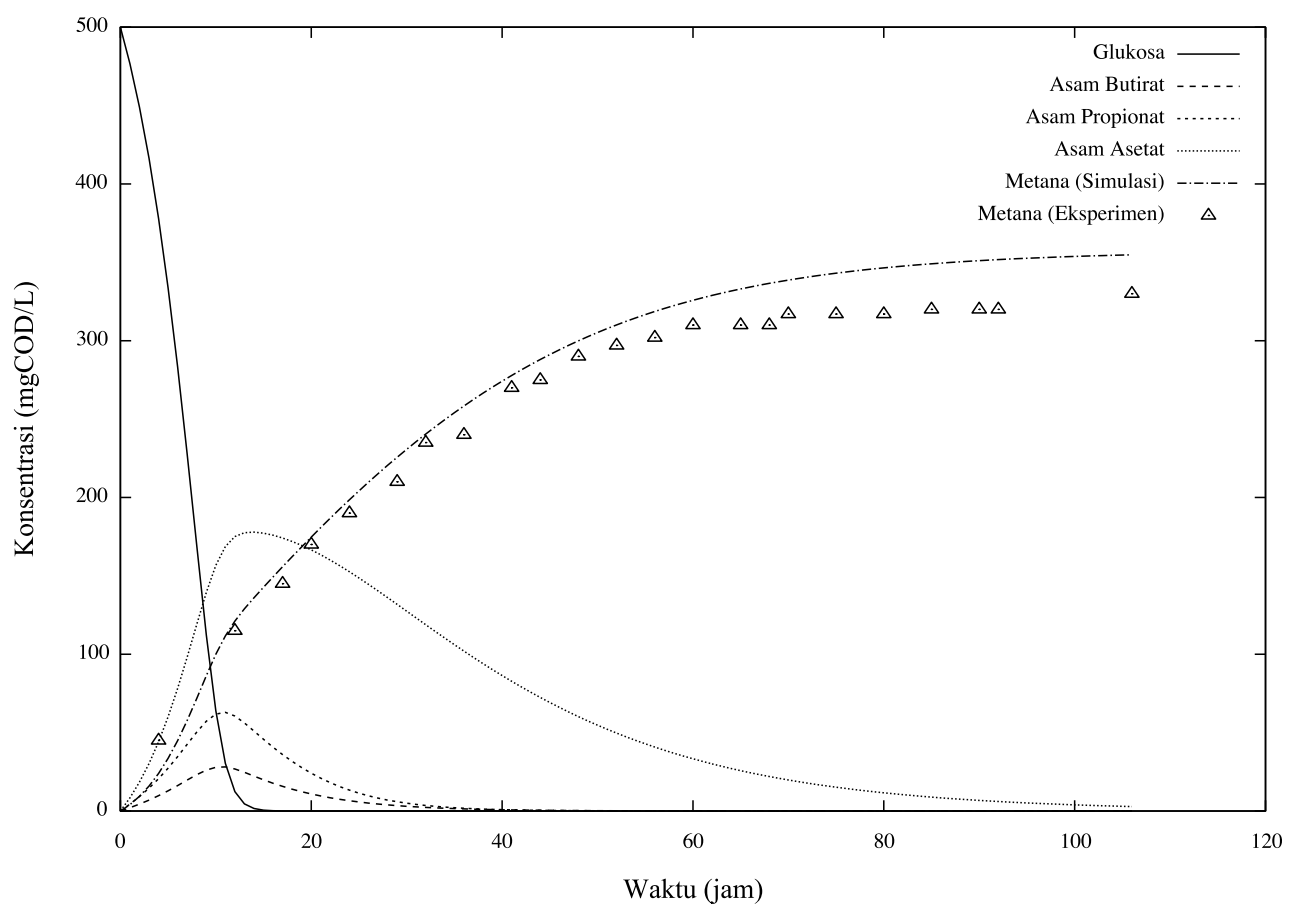

Gambar 6. Perbandingan hasil simulasi menggunakan parameter teroptimasi dengan data eksperimen.

yang lain akan terkonversi menjadi asam asetat. Komposisi spesi di periode akhir reaksi hanya menyisakan metana sebagai spesi tunggal sesuai dengan Gambar 1. Konsentrasi metana pada akhir simulasi adalah $354,79 \mathrm{mgCOD} / \mathrm{L}$. Konsentrasi metana akhir ini sangat dipengaruhi oleh komposisi substrat awal yang digunakan. Profil pH campuran pada Gambar 7 menunjukkan bahwa kondisi sistem pada awal simulasi cenderung netral yaitu 6,8. Selanjutnya nilai $\mathrm{pH}$ mengalami kenaikan hingga 8,0 dan menurun sampai pH 7,6 di akhir simulasi. Ada dua faktor yang dapat menjelaskan kondisi $\mathrm{pH}$ campuran yang relatif netral. Faktor pertama adalah jenis spesi asam yang terlibat merupakan asam lemah. Faktor kedua adalah keberadaan ion bikarbonat yang bersifat basa sehingga dapat mengimbangi produksi spesi asam selama reaksi berlangsung.

\section{KESIMPULAN}

Anaerobic Digestion Model No. 1 (ADMI) dapat digunakan untuk memodelkan produksi biogas dari substrat glukosa. Hal ini diindikasikan oleh kecenderungan dinamika konsentrasi hasil simulasi yang mendekati data eksperimen. Akurasi perhitungan dapat ditingkatkan dengan mengoptimasi parameter simulasi menggunakan algoritma genetika sehingga tingkat kesalahan yang dihitung dengan MAPE dapat berkurang. Jumlah parameter yang dioptimasi dapat direduksi dengan menghitung indeks sensitivitas masing-masing parameter. Dinamika konsentrasi spesi yang lebih akurat dapat digambarkan melalui simulasi menggunakan parameter teroptimasi.

\section{REFERENCES}

[1] Satpathy, S., Steinigeweg, S., Uhlenhut, F., \& Siefert, E. (2013). Application of Anaerobic Digestion Model 1 (ADM1) for Prediction of Biogas Production. International Journal of Scientific \& Engineering Research, 4(12), 86-89. Available: http://www.ncbi.nlm.nih.gov/pubmed/16180468 


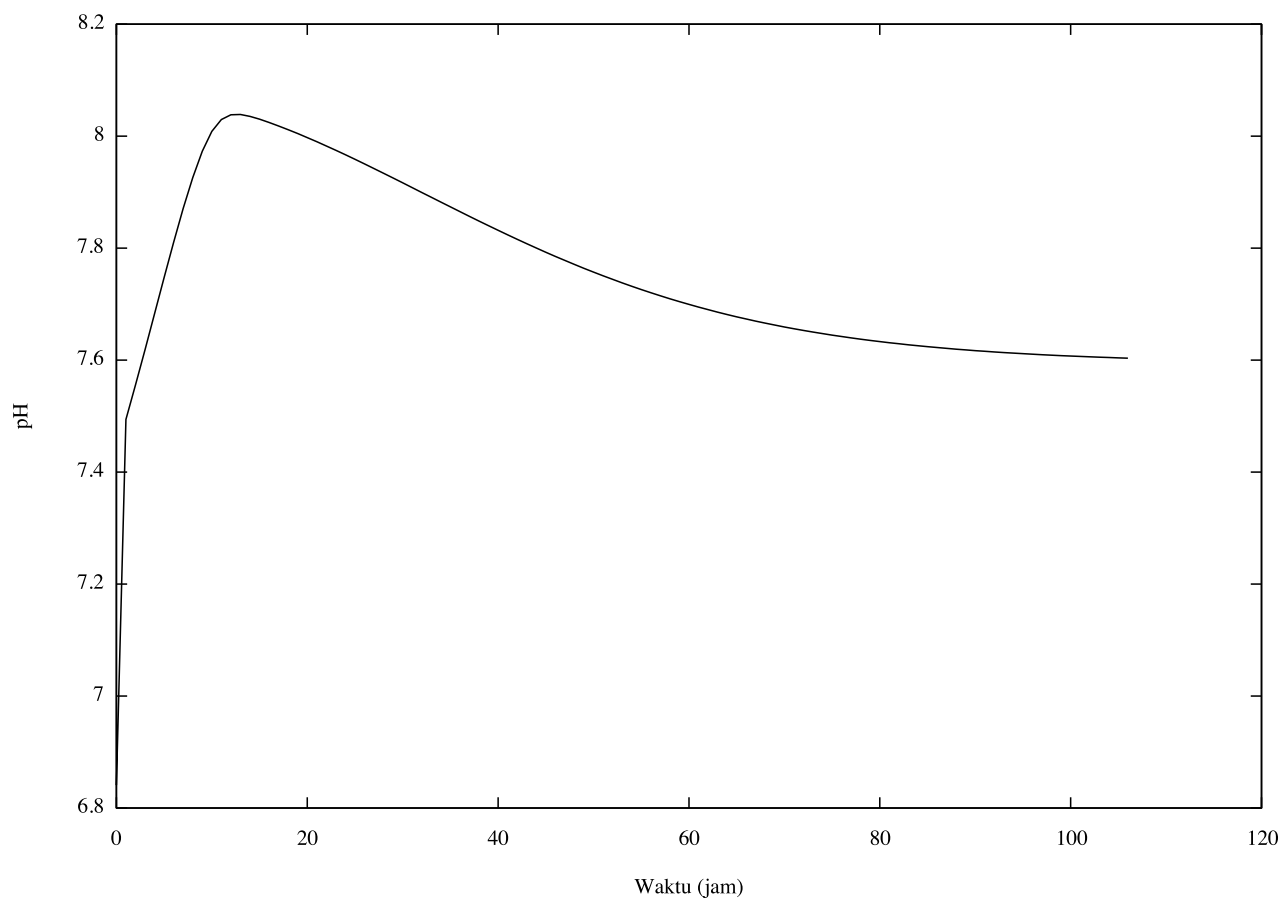

Gambar 7. Profil pH selama simulasi.

[2] Schon, M. (2010). Numerical modelling of anaerobic digestion processes in agricultural biogas plants. Innsbruck: University Press.

[3] Yu, L., Wensel, P. C., Ma, J., \& Chen, S. (2013). Mathematical Modeling in Anaerobic Digestion (AD). J Bioremed Biodeg Journal of Bioremediation \& Biodegradation, S4.

[4] Jeong, H., Suh, C., Lim, J., Lee, S., \& Shin, H. (2004). Analysis and application of ADM1 for anaerobic methane production. Bioprocess Biosyst Eng Bioprocess and Biosystems Engineering, 27(2), 81-89. Available: http://www.ncbi.nlm.nih.gov/pubmed/15592879

[5] Eaton, J. W., Bateman, D., Hauberg, S., \& Wehbring, R. (2014). GNU Octave version 3.8.1 manual: A high-level interactive language for numerical computations. CreateSpace Independent Publishing Platform.

[6] Batstone, D. J., Keller, J., Angelidaki, I., Kalyuzhnyi, S. V., Pavlostathis, S. G., Rozzi, A., ... Vavilin, V. A. (2002). The IWA Anaerobic Digestion Model No 1 (ADM1). Water Science and Technology: A Journal of the International Association on Water Pollution Research, 45(10), 65-73.

[7] Rosen, C., \& Jeppsson, U. (2006). Aspects on ADM1 implementation within the BSM2 framework. Department of Industrial Electrical Engineering and Automation Lund University, Lund, Sweden.

[8] Solon, Kimberly. Anaerobic Digestion of Manure Improved Modelling by Taking into Account Physicochemical Effects. Thesis. Universiteit Gent, 2011.

[9] Lyseng, Benjamin C., Wenche Bergland, Deshai Botheju, Finn Haugen, and Rune Bakke. Biogas Reactor Modelling with ADM1. 2012. Telemark University College, Porsgrunn.

[10] Bouma, Eelke. Building an Explorative Model of the Biogas Production Process in an Anaerobic Digester. Thesis. Wageningen University, 2014.

[11] Lidholm, Oscar, and Elin Ossiansson. Modeling Anaerobic Digestion -Validation and Calibration of the Siegrist Model with Uncertainty and Sensitivity Analysis. Thesis. Lunds Universitet, 2008. 


\section{DAFTAR NOTASI}

\begin{tabular}{|c|c|c|}
\hline Notasi & Deskripsi & Satuan \\
\hline$C_{i}$ & Kandungan karbon pada komponen $i$ & kmol.kgCOD $^{-1}$ \\
\hline$K_{A, B_{i}}$ & Tetapan laju asam basa komponen $i$ & $\mathrm{M}^{-1} \cdot \mathrm{d}^{-1}$ \\
\hline$k_{d e c}$ & Tetapan laju peluruhan orde pertama mikroba & $\mathrm{d}^{-1}$ \\
\hline$k_{m}$ & Tetapan laju reaksi maksimum Monod spesifik & kgCOD.m $m^{-3}$ _S.kgCOD.m ${ }^{-3}{ }_{\text {X. }}$ X.d ${ }^{-1}$ \\
\hline$K_{a}$ & Tetapan kesetimbangan asam basa & $\mathrm{M}$ \\
\hline$K_{S}$ & Tetapan setengah jenuh Monod & kgCOD. $\mathrm{m}^{-3}$ \\
\hline$S_{i}$ & Komponen terlarut $i$ & kgCOD.m $\mathrm{m}^{-3}$ \\
\hline$X_{i}$ & Komponen partikulat/mikroba $i$ & kgCOD.m $\mathrm{m}^{-3}$ \\
\hline$Y_{\text {substrat }}$ & Jumlah biomassa yang dihasilkan dari substrat & kgCOD.m ${ }^{-3} \_X X . k g C O D \_S$ \\
\hline$v_{i, j}$ & Koefisien laju untuk komponen $i$ pada proses $j$ & \\
\hline$f_{\text {product, substrate }}$ & Jumlah produk reaksi dari substrat & kgCOD.kgCOD ${ }^{-1} \mathrm{~S}$ \\
\hline$\rho_{i}$ & Laju reaksi proses $i$ & kgCOD.kgCOD ${ }^{-1} \mathrm{~S}$ \\
\hline
\end{tabular}


